\begin{tabular}{|c|c|c|c|c|}
\hline JURNAL & \multirow{2}{*}{ NOLUME 3 } & \multirow{2}{*}{ NOMOR 1 } & HALAMAN 41-50 & $\begin{array}{l}\text { ISSN 2655-8823 }(p) \\
\text { KOLABORAS 2656-1786 }(e)\end{array}$ \\
\hline
\end{tabular}

\title{
EDUKASI KEWIRAUSAHAAN UNTUK MENGEMBANGKAN KETERAMPILAN PEMASARAN PELAKU USAHA OPAK DI DESA CIBODAS SOLOKAN JERUK
}

\author{
Hery Wibowo, Syahrul Hidayat, Hanifah Arroyana, Adrianti Nur Fitria Sofandi, \\ Adit Djati Permana, Naura Salsabila \\ Departemen Kesejahteraan Sosial FISIP, Universitas Padjadjaran
}

E-mail: hery.wibowo@unpad.ac.id

Wandi Adiansah

Pusat Studi CSR, Kewirausahaan Sosial dan Pemberdayaan Masyarakat, Universitas Padjadjaran

E-mail: adiansahw@gmail.com

\begin{abstract}
ABSTRAK
Revolusi Industri 4.0 telah mengubah wajah industry. Perdangangan berbasis daring/internet semakin masif dilakukan oleh para pengusaha baik skala besar maupun kecil. Isu ini, disatu sisi dapat mendorong perkembangan usaha di kotakota besar. Namun demikian, hal ini juga dapat menjadi ancaman bagi pelaku usaha kecil dan menengah di pedesaan yang belum mendapatkan edukasi terkait pemasaran digital. Aksi pengabdian masyarakat ini bertujuan untuk membantu para pengusaha Opak di Desa Solokan Jeruk, agar mampu meningkatkan bentuk dan varian jalur pemasarannya. Kegiatan dimulai dengan melakukan observasi dan wawancara mendalam terhadap pelaku usaha, untuk kemudian dirumuskan bentuk dan jenis pelatihan yang sesuai dengan kebutuhan pelaku usaha.
\end{abstract}

Kata kunci: kewirausahaan; opak; pemasaran digital; UMKM.

\section{LATAR BELAKANG}

Dunia saat ini telah memasuki revolusi industry yang keempat. Revolusi industri pertama terjadi pada tahun 1784 di Inggris sejak penemuan mesin uap dan mekanisasi yang mulai menggantikan pekerjaan manusia. Revolusi industri kedua terjadi di akhir abad ke-19 dengan adanya mesin mesin produksi tenaga listrik yang digunakan untuk melakukan produksi secara masal. Revolusi ketiga pada tahun 1970 dimulai dengan adanya pemakaian teknologi computer untuk otomasi manufaktur. Perkembangan yang pesat dari adanya teknologi tersebut memberikan gagasan untuk mengintegrasikan seluruh teknologi ke dalam berbagai bidang industri. Gagasan inilah yang memunculkan ide revolusi industri ke empat (Drath \& Horch, 2014).

Industri 4.0 lahir tahun 2011 di Jerman. Jerman merupakan negara yang memiliki kepentingan yang besar, karena industry 4.0 berkaitan dengan kebijakan rencana pembangunan yang disebut High-Tech Strategy 2020. Kebijakan ini memiliki tujuan yaitu mempertahankan Jerman dalam dunia manufaktur (Heng, 2014). Konsep industri 4.0 juga turut digunakan oleh beberapa negara, namun dalam istilah yang berbeda seperti Smart Industry, Advanced Manufacturing, Smart Factories, Industrial Internet of Things, dan lain-lain. Meski istilah yang digunakan berbeda-beda, namun semuanya memiliki tujuan yang sama yaitu meningkatkan daya saing industri dalam menghadapai pasar global yang dinamis. Hal ini terjadi karena pesatnya perkembangan pemanfaatan teknologi digital di berbagai bidang (Prasetyo \& Sutopo, 2018).

Industri 4.0 adalah integrasi dari Cyber Physical System (CPS) dan Internet of Things and Services (loT dan loS) ke dalam proses industry yang meliputi manufaktur dan logistik, serta proses lainnya. CPS merupakan penggabungan teknologi antara 


\begin{tabular}{|c|c|c|c|c|}
\hline JURNAL & VOLUME 3 & NOMOR 1 & HALAMAN 41-50 & $\begin{array}{l}\text { ISSN 2655-8823 }(p) \\
\text { ISSN 2656-1786 }(e)\end{array}$ \\
\hline
\end{tabular}

dunia maya dan dunia nyata, melalui integrasi proses fisik dan komputasi secara close loop, sedangkan loS adalah seluruh aplikasi layanan yang dimanfaatkan oleh pemakai baik secara internal maupun antar organisasi. Industri 4.0 memiliki enam prinsip, yaitu interoperability, virtualisasi, desentralisasi, kemampuan real time, berorientasi layanan dan bersifat modular (Prasetyo \& Sutopo, 2018).

Industri 4.0 memiliki banyak model, salah satunya yang dinilai lebih komprehensif adalah model Fraunhofer Industrie 4.0 layer model karena unsur tangible dimasukkan lebih banyak (Neugebauer, Hippmann, Leis, \& Landherr, 2016). Model ini disusun setelah melalui beberapa tahap yaitu, ekstraksi dokumen dari berbagai penelitian dan hasil wawancara para ahli. Model ini tersusun atas tiga lapisan utama, dengan lapisan inti terkait produksi dan terdapat sepuluh bagian teknologi inti, yaitu: a. Engineering

b. Manufacturing technologies and organization

c. Machines

d. Smart capabilities

e. Robotics and human-robot collaboration

f. Production planning control

g. Logistics

h. Work organization

i. Workplace design and assistance

j. Resource and energy efficiency

Lapisan selanjutnya adalah aspek mengenai teknologi informasi dan komunikasi yang sangat menunjang realisasi konsep industry 4.0. lapisan terluar mengenai transformasi perusahaan akibat implementasi industry 4.0, seperti bisnis, manajemen, dan sumber daya manusia (Neugebauer et al., 2016).

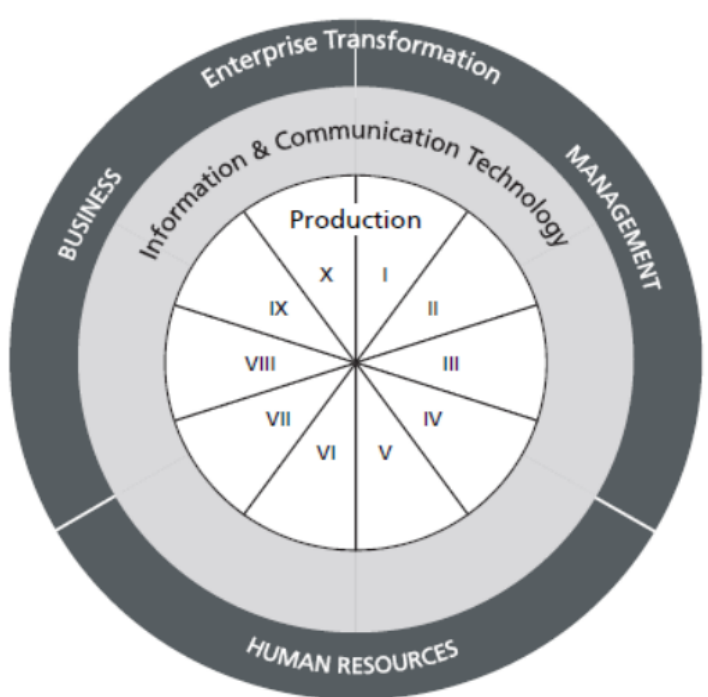

Gambar 1. Struktur Fraunhofer Industrie 4.0 layer model (Neugebauer et al., 2016) 


\begin{tabular}{|c|c|c|c|c|}
\hline JURNAL & VOLUME 3 & NOMOR 1 & HALAMAN 41-50 & $\begin{array}{l}\text { ISSN 2655-8823 }(p) \\
\text { ISSN 2656-1786 }(e)\end{array}$ \\
\hline
\end{tabular}

Tabel 1. Aspek Industri 4.0 (Prasetyo \& Sutopo, 2018)

\begin{tabular}{|c|c|c|}
\hline No. & Aspek & Deskripsi \\
\hline 1 & Standardisasi & $\begin{array}{l}\text { Meliputi segala usaha menyusun standar dan referensi dalam } \\
\text { implementasi Industri } 4.0\end{array}$ \\
\hline 2 & Pemodelan & $\begin{array}{l}\text { Meliputi usaha untuk memodelkan sistem yang kompleks di } \\
\text { industry }\end{array}$ \\
\hline 3 & $\begin{array}{l}\text { Jaringan } \\
\text { komunikasi }\end{array}$ & $\begin{array}{l}\text { Ketersediaan teknologi perangkat keras atau lunak untuk } \\
\text { pertukaran informasi dan data yang cepat dan real time. }\end{array}$ \\
\hline 4 & Safety and security & $\begin{array}{l}\text { Segala hal terkait keamanan sistem pengolahan data dan keamanan } \\
\text { penggunaan teknologi bagi manusia. }\end{array}$ \\
\hline 5 & $\begin{array}{l}\text { Sumber } \\
\text { manusia }\end{array}$ & $\begin{array}{l}\text { Meliputi usaha untuk mentransformasi sumber daya manusia agar } \\
\text { siap menghadapi perubahan akibat Industri } 4.0\end{array}$ \\
\hline 6 & Hukum & $\begin{array}{l}\text { Meliputi usaha untuk menyusun kerangka hukum dalam } \\
\text { implementasi Industri } 4.0 \text { (kontrak, perjanjian, aturan, } \mathrm{dsb} \text { ). }\end{array}$ \\
\hline 7 & $\begin{array}{l}\text { Efisiensi sumber } \\
\text { daya }\end{array}$ & $\begin{array}{l}\text { Meliputi segala usaha untuk melakukan efisiensi sumber daya } \\
\text { (energi, biaya, dsb) akibat implementasi teknologi Industri } 4.0\end{array}$ \\
\hline 8 & Teknologi CPS & $\begin{array}{l}\text { Segala usaha terkait pengembangan teknologi CPS, IoT, } \\
\text { virtualisasi, yang menjadi kunci teknologi Industri } 4.0\end{array}$ \\
\hline 9 & Smart factory & $\begin{array}{l}\text { Meliputi pengembangan sistem manufaktur/produksi yang } \\
\text { otomatis, cerdas, modular dan adaptif. }\end{array}$ \\
\hline 10 & Bisnis & $\begin{array}{l}\text { Meliputi penemuan model bisnis baru atau perubahan proses bisnis } \\
\text { akibat penerapan Industri } 4.0\end{array}$ \\
\hline 11 & Desain kerja & $\begin{array}{l}\text { Meliputi pengembangan dan penelitian terkait perubahan sistem } \\
\text { kerja yang akan dihadapi oleh pekerja. }\end{array}$ \\
\hline 12 & Services & $\begin{array}{l}\text { Meliputi segala usaha dalam mengolah big data dan membuat } \\
\text { aplikasi pemanfaatannya }\end{array}$ \\
\hline 13 & $\begin{array}{l}\text { Manajemen } \\
\text { organisasi }\end{array}$ & $\begin{array}{l}\text { Terkait perubahan dan pengembangan model manajemen dan } \\
\text { organisasi karena penerapan Industri } 4.0\end{array}$ \\
\hline 14 & $\begin{array}{l}\text { Rekayasa produk } \\
\text { end to end }\end{array}$ & $\begin{array}{l}\text { Terkait rekayasa produk atau layanan yang terdigitalisasi selama } \\
\text { siklus hidupnya (smart product) }\end{array}$ \\
\hline
\end{tabular}




\begin{tabular}{|c|c|c|c|c|}
\hline JURNAL & \multirow{2}{*}{ VOLUME 3 } & \multirow{2}{*}{ NOMOR 1 } & HALAMAN 41-50 & $\begin{array}{l}\text { ISSN 2655-8823 }(p) \\
\text { ISSN 2656-1786 }(e)\end{array}$ \\
\hline
\end{tabular}

Model kerangka Industri 4.0 sampai saat ini masih dikembangkan, hal ini dilakukan untuk dapat mewujudkan model yang secara global dapat digunakan sebagai acuan untuk berbagai tipe serta level industri. Oleh karena itu, ditemukan terdapat empat belas aspek di Industri 4.0 (Tabel 1) (Prasetyo \& Sutopo, 2018).

UMKM merupakan salah satu penopang roda perekonomian di Indonesia dan penggerak industri skala kecil di masyarakat. Hal ini dikarenakan seluruh aspek yang berkaitan dengan manusia, seperti sektor sandang, pangan, dan papan. Salah satu contoh di sektor sandang UMKM sangat berperan aktif, seperti usahadi industri pengolahan hasil pertanian. Peran UMKM di masyarakat salah satunya adalah mengurangi tingkat pengangguran karena UMKM berperan aktif menyerap tenaga kerja. Selain itu, UKM juga bermanfaat dalam pendapatan nasional, yaitu adanya kontribusi melalui pajak yang dikeluarkan (Kristiyanti \& Rahmasari, 2015).

Pola pikir kewirausahaan, perlu dimiliki oleh pelaku industri, khususnya dalam menghadapi persaingan global. Kewirausahaan (Sukoco, Fordian \& Rusdin (2019) adalah mengidentifikasi, mengembangkan, dan membawa visi tersebut bisa berupa ide inovatif, peluang, cara yang lebih baik dalam menjalankan sesuatu (Sukoco, Fordian, \& Rusdin, 2019). Pola pikir ini diharapkan mampu mendorong pola adaptasi yang baik dalam menghadapi revolusi industri 4.0. Industri 4.0 bukan hanya sekedar high-tech. Esensi industri tetap untuk memenuhi kebutuhan konsumen. Industri 4.0 harus mampu memadukan antara inovasi berbasis sains melalui aplikasi-aplikasi dan inovasi berawal dari konsumen guna memenuhi kebutuhan mereka (Karlina, Halim, Azizi, Athusholihah, \& Tarliyah, 2020).

Jenis UMKM yang bergerak di industri pengolahan hasil pertanian salah satunya, yaitu opak. Usaha opak di Desa Cibodas cukup dikenal karena sudah berkembang dan dipasarkan ke penjuru Jawa Barat, salah satunya di sentra oleh-oleh. Keunikan dari opak Desa Cibodas yaitu menjaga keaslian opak yang dilakukan turun temurun dari tahun 1980-an. Opak merupakan salah satu makanan khas tradisional daerah Jawa Barat. Opak yang diproduksi oleh pelaku usaha di Desa Cibodas menggunakan bahan baku ketan yang memiliki dua varian rasa, yaitu asin dan manis. Opak sering dihidangkan untuk acara pernikahan dan kajian keagamaan, selain itu juga biasa dijadikan sebagai buah tangan oleh pelancong. Saat ini permasaran opak masih dilakukan dengan pemasaran offline, sedangkan usaha opak ini cukup mumpuni untuk dipasarkan dalam pemasaran secara digital atau online.

Digital marketing adalah suatu kegiatan pemasaran termasuk didalamnya upaya membangun citra positif (branding) menggunakan berbagai media berbasis internet. Sistem digital marketing banyak digunakan karena lebih mudah, cepat, dan terukur sehingga memudahkan dalam pendataan produk yang akan dijual. Selain itu juga termasuk adanya jaminan kualitas produk dan kenyamanan pembeli produk (Fawaid, 2017). Adanya digital marketing ini merupakan hasil dari berkembangnya Marketing 4.0.

Industri 4.0 sejalan dengan Marketing 4.0, dimana Marketing 4.0 merupakan suatu pendekatan dengan mengacu pada pola perilaku konsumen era digital dengan kerangka kerja 5A (Aware, Appeal, Ask, Act, dan Advocate). Saat ini pemasaran telah berkembang dari semula yang berorientasi pada kualitas produk yang akan dijual (Marketing 1.0), kemudian berorientasi pada pelanggan (Marketing 2.0), dan kemudian berorientasi pada hubungan dengan pelanggan yang dapat menentukan masa depan perusahaan (Marketing 3.0) (Kotler, Kartajaya, \& Setiawan, 2017).

Marketing 1.0, perusahaan lebih fokus pada bagaimana cara menjual produk sebanyak - banyaknya tanpa memikirkan persepsi dari konsumen. Selanjutnya berkembang Marketing 2.0 dimana 


\begin{tabular}{|c|c|c|c|c|}
\hline JURNAL & \multirow{2}{*}{ VOLUME 3 } & \multirow{2}{*}{ NOMOR 1 } & HALAMAN 41-50 & $\begin{array}{l}\text { ISSN 2655-8823 }(p) \\
\text { ISSN 2656-1786 }(e)\end{array}$ \\
\hline
\end{tabular}

perusahaan menjual produk dengan berusaha menyentuh hati konsumen, namun cara ini diklaim terlalu tua karena menganggap konsumen sebagai objek yang pasif. Marketing 3.0 tidak lagi menganggap konsumen pasif, namun sebagai manusia yang memiliki akal, mampu berpikir, dan mempunyai harapan, sehingga perusahaan tidak hanya memasarkan produk, tetapi mempunyai visi, misi, dan nilai yang beriringan dengan konsumennya (Kotler et al., 2017).

Seiring berkembangnya kemajuan di bidang teknologi, yang digunakan dalam Marketing 4.0 sebagai pendekatan kepada konsumen dengan cara yang baru. Marketing 4.0 didukung oleh teknologi yang canggih, dan adanya analisis big data, sehingga perusahaan dapat melayani konsumen secara manusiawi. Perusahaan semakin mudah melakukan interkasi antar perusahaan dan konsumen (Kotler et al., 2017).

Aktivitas pengabdian masyarakat ini menggunakan metode penelitian dan pengembangan (research \& development), yaitu bertujuan untuk menghasilkan model pemasaran terbaik yang selaras dengan perkembangan revolusi industry dan juga perkembangan pemasaran global. Sejumlah Langkah yang dilakukan adalah sebagai berkut akan diuraikan selanjutnya.

\section{METODE PENELITIAN}

Penelitian ini dilakukan menggunakan metode penelitian dan pengembangan (research and development). Richey \& Kelin (2009) dalam Sugiyono (2020) menjelaskan bahwa ruang lingkup penelitian dan pengembangan adalah: (1) Penelitian tentang proses dan dampak dari produk yang dihasilkan dari perencanaan dan penelitian pengembangan, (2) Penelitian tentang perancangan (desain) dan proses pengembangan secara keseluruhan atau komponen dari sebagian proses.

Salah satu hasil akhir dari digunakannya metode penelitian dan pengembangan (research and development method) adalah model pembelajaran (Sugiyono, 2019). Secara umum penelitian ini bertujuan untuk menghasilkan model ataupun pola pemasaran terbaik baik pelaku UKM.

Secara umum langkah-langkah penelitian yang menggunakan metode penelitian dan pengembangan (research and development) adalah sebagai berikut (Sugiyono, 2019): Identifikasi potensi dan masalah, pengumpulan informasi, desain produk, validasi desain, perbaikan desain dan uji coba produk.

Berikut sejumlah aktivitas yang dilakukan:

1. Identifikasi Potensi dan Masalah.

Proses ini dilakukan dengan melakukan observasi kepada lokasi usaha yang ada di Desa Cibodas. Observasi adalah tehnik pengamatan sistematis yang diikuti dengan tehnik pencatatan sistematis juga untuk membantu perolehan data yang mendasarai pernyataan spesifik dari individu atau kelompok yang tercermin melalui tingkah lakunya sehingga nantinya dapat dimaknakan.

2. Pengumpulan Informasi.

Proses pengumpulan informasi dilakukan dengan melakukan wawancara. Wawancara merupakan suatu metode untuk mendapatkan informasi yang didapatkan karena adanya pertemuan antara subjek dan peneliti dalam situasi tertentu (Rosaliza, 2015). Wawancara adalah salah satu bentuk pengumpulan data dalam penelitian kualitatif. Wawancara memiliki beberapa jenis, namun jenis wawancara yang digunakan adalah wawancara tidak berstruktur. Wawancara tidak berstruktur bersifat fleksibel dan peneliti mengikuti pemikiran narasumber. Pewawancara dapat dengan bebas memberikan pertanyaan kepada narasumber dalam urutan apapun yang bergantung pada jawaban (Rachmawati, 2007).

Wawancara tidak berstruktur lebih baik digunakan apabila peneliti 


\begin{tabular}{|c|c|c|c|c|}
\hline JURNAL & \multirow{2}{*}{ VOLUME 3} & \multirow{2}{*}{ NOMOR 1 } & HALAMAN 41-50 & $\begin{array}{l}\text { ISSN 2655-8823 }(p) \\
\text { ISSN 2656-1786 }(e)\end{array}$ \\
\hline
\end{tabular}

melakukan wawancara lebih dari satu kali. Wawancara ini memiliki kekurangan dan kelebihan. Salah satu kelebihannya yaitu akan menghasilkan data yang banyak, namun juga memiliki kekurangan yaitu dross rate (informasi yang tidak berguna) tinggi (Rachmawati, 2007). Proses wawancara dilakukan kepada pelaku usaha Opak di lingkungan Desa Cibodas.

3. Membangun Desain Produk, Validasi desan dan Perbaikan Desain.

Produk yang dihasilkan dalam penelitian yang menggunakan metode penelitian dan pengembangan (research and development) bermacammacam (Sugiyono 2020). Pada tahap ini peneliti membangun sebuah model solusi dari permasalahan yang dihadapi.

4. Uji Coba Produk.

Tahapan ini dilakukan dengan workshop/lokakarya dan pelatihan. Workshop atau lokakarya adalah pertemuan orang yang bekerja sama dalam kelompok kecil, biasanya dibatasi pada masalah yang dihadapi sendiri (Suprayekti \& Anggraeni, 2017). Peserta yang ikut dalam kegiatan workshop diharpkan dapat menghasilkan produk tertentu. Susunan acara lokakarya yaitu identifikasi masalah, pencarian, dan usaha pemecahan masalah dengan referensi dan latar belakang yang tersedia (Suprayekti \& Anggraeni, 2017).

Menurut Rosmaryanti (2010) ada beberapa jenis workshop berdasarkan sifatnya yaitu bersifat mengikat, dan tidak mengikat. Prosedur yang dilakukan dalam workshop diantaranya yaitu, (1) merumuskan tujuan untuk memperoleh hasil akhir yang akan dicapai, (2) merumuskan pokok masalah yang akan dibahas secara rinci untuk mempermudah proses berjalannya kegiatan, dan (3) menentukan prosedur pemecahan masalah.
Workshop merupakan salah satu program belajar bagi orang dewasa. secara umum proses kegiatan belajar orang dewasa yang terdiri daru tiga fase, yaitu perencanaan, pelaksanaan, dan evaluasi. Tahap perencanaan terdiri dari perumusan tujuan pembelajaran; pengembangan alat evaluasi dan hasil belajar; analisis tujuan belajar dan identifikasi kemampuan belajar warga; dan penyusunan strategi belajar membelajarkan. Tahap pelaksanaan terdiri dari pelaksanaan kegiatan belajar - membelajarkan dan pemanfaatan hasil belajar. Tahap evaluasi meliputi evaluasi hasil dan program belajar serta perbaikan program kegiatan belajar (Suprayekti \& Anggraeni, 2017).

Selanjutnya adalah pelatihan. Pelatihan adalah modifikasi perilaku terencana dan sistematis melalui acara pembelajaran, kegiatan dan program yang hasilnya yaitu peserta memiliki peningkatan pengetahuan, keterampilan, kompetensi, dan kemampuan untuk melaksanakan pekerjaan secara efektif (Nassazi, 2013).

\section{Lokasi dan Waktu Kegiatan}

Kegiatan ini dilakukan di Desa Cibodas Kecamatan Solokanjeruk Kabupaten Bandung Provinsi Jawa Barat. Secara geografi wilayah Desa Cibodas berbatasan langsung dengan Desa Jelegong, Desa Sukamulya, dan Desa Haur Pugur di bagian utara, bagian selatan berbatasan dengan Desa Majasetra, dan Desa Majakerta. Bagian barat berbatasan dengan Desa Langensari, dan bagian timur berbatasan dengan Desa Padamukti, dan Desa Panyadap. Karya tulis ini dilaksanakan dalam rentang waktu 1 bulan, dari bulan Januari - Februari 2020.

\section{PEMBAHASAN}

Hasil dari penelitian awal yang dilakukan, yaitu melalui aktivitas wawancara dan observasi, didapatkan luaran berupa kondisi awal. Berbasis kajian 


\begin{tabular}{|c|c|c|c|c|}
\hline JURNAL & \multirow{2}{*}{ VOLUME 3 } & \multirow{2}{*}{ NOMOR 1 } & HALAMAN 41-50 & $\begin{array}{l}\text { ISSN 2655-8823 }(p) \\
\text { ISSN 2656-1786 }(e)\end{array}$ \\
\hline
\end{tabular}

awal yang dilakukan pada tahap identifikasi potensi dan masalah, didapatkan informasi bahwa permasalahan yang dihadapai adalah strategi pemasaran yang perlu ditingkatkan untuk menghadapi persaingan dalam era revolusi industry dan pemasaran 3.0. Selanjutnya tim membangun semacam modul pemasaran digital, yaitu berupa rangkaian program workshop dan pelatihan pemasaran digital, termasuk contoh ruang pemasaran (market place) di dunia maya.

Pelaksanaan kegiatan diawali dengan pembagian job description yang melibatkan seluruh peserta KKN pada tanggal 13 Januari 2020. Pada pertemuan ini dihasilkan tim workshop yang dibantu dengan beberapa divisi untuk menunjang kegiatan tersebut melalui musyawarah untuk mencapai sebuah keputusan. Penentuan jobdesc bertujuan untuk merumuskan teknis dan konsep workshop lebih terarah sehingga meminimalisir kendala pada acara berlangsung dengan pembagian jobdesc yang jelas. Pemilihan tema workshop pemasaran online merujuk pada UMKM di Desa Cibodas yang belum mengenal pemasaran online karena pemasaran produk mereka dilakukan secara konvensional dari mulut ke mulut atau warga yang datang secara langsung membeli ke rumah pelaku usaha sehingga pendapatan yang mereka dapatkan kurang maksimal.

Persiapan kegiatan workshop dilakukan selama dua minggu setelah pembagian tugas antar peserta KKN. Kegiatan persiapan meliputi pembuatan teknis acara, materi workshop, logistik, konsumsi dan kegiatan menyebarkan undangan untuk para stakeholders yang diundang pada acara workshop. Stakeholders yang diundang merupakan pelaku UMKM di Desa Cibodas, perangkat desa, karang taruna, BUMDES, serta perwakilan dari GAPOKTAN Desa Cibodas. Materi yang diberikan merupakan gambaran umum sekaligus pengenalan akan pemasaran online, materi yang telah dibuat kemudian dilakukan revisi oleh Bapak Herry Wibowo selaku DPL KKN Desa Cibodas dengan masukan yang beliau berikan materi yang akan diberikan untuk kegiatan workshop menjadi lebih baik.

Program yang dilaksanakan berupa workshop mengenai kewirausahaan di era digital. (1) Materi manajemen pemasaran yang diberikan mengenai etos kerja dan cara melakukan pemasaran produk secara efektif, tepat sasaran, dan lebih luas dengan memanfaatkan pemasaran berbasis online. (2) Materi manajemen keuangan mengenai sistem kerjasama dan bantuan usaha yang diberkaitan dengan BUMDes (3) Materi motivasi diberikan dengan cara focus group discussion (FGD) secara berkelompok untuk membahas hambatan yang dihadapi dan solusi yang ditawarkan. Hal ini dilakukan untuk memotivasi para pelaku usaha agar terus maju, terus berinovasi, dan pantang menyerah.

Program yang dilaksanakan berupa workshop mengenai kewirausahaan di era digital. (1) Materi manajemen pemasaran yang diberikan mengenai etos kerja dan cara melakukan pemasaran produk secara efektif, tepat sasaran, dan lebih luas dengan memanfaatkan pemasaran berbasis online. (2) Materi manajemen keuangan mengenai sistem kerjasama dan bantuan usaha yang diberkaitan dengan BUMDes (3) Materi motivasi diberikan dengan cara focus group discussion (FGD) secara berkelompok untuk membahas hambatan yang dihadapi dan solusi yang ditawarkan. Hal ini dilakukan untuk memotivasi para pelaku usaha agar terus maju, terus berinovasi, dan pantang menyerah.

Pada tanggal 27 Januari 2020 dilaksanakan kegiatan workshop pemasaran online. Kegiatan diawali dengan membagikan handout materi kepada setiap peserta agar peserta dapat membaca kembali materi yang diberikan. Penyampaian materi dilakukan oleh Ariq yang merupakan anggota tim workshop.

\section{Materi Presentasi}

a. Pemasaran Online.

Pemasaran online adalah pemasaran yang dilakukan melalui sistem 


\begin{tabular}{|c|c|c|c|c|}
\hline JURNAL & \multirow{2}{*}{ NOLUME 3} & NOMOR 1 & HALAMAN 41-50 & $\begin{array}{l}\text { ISSN 2655-8823 }(p) \\
\text { ISSN 2656-1786 }(e)\end{array}$ \\
\hline
\end{tabular}

komputer online interaktif yang menghubungkan konsumen dan penjual secara elektronik.

b. Manfaat pemasaran online.

Bagi Konsumen.

1) Dapat berbelaja tanpa mengenal ruang dan waktu, karena marketplace berlaku 24 jam

2) Konsumen dapat mencari dan membeli barang yang mungkin akan sulit ditemukan di pasar fisik, konsumen hanya tinggal memasukkan kata kunci dari barang tersebut. Karena hampir semua jenis barang tersedia di marketplace online

3) Konsumen mendapatkan penawaran terbaik dari suatu barang. Hal ini karena konsumen dapat membandingkan harga barang dan memilih secara leluasa sebelum memutuskan untuk membeli

Bagi Penjual:

1) Penjual dapat menyesuaikan harga dan produk yang cepat terhadap kondisi pasar

2) Penjual dapat dengan cepat menambahkan produk pada katalognya dan mempromosikan secara langsung

3) Biaya yang dikeluarkan lebih rendah. Daripada menyewa tempat secara fisik, menjadi mitra di marketplace online jauh lebih murah

4) Cakupan pasar yang lebih luas dari pemasaran secara fisik bahkan mencapai cakupan internasional. Dimanapun calon konsumen berada, selama memiliki akses internet mereka bisa mengetahui barang yang akan penjual jual.

c. Strategi Pemasaran Online.

1) Melalui website atau blog.

2) Usaha yang dibangun dapat diakses selama 24 jam. Web dapat menjelaskan secara rinci deskripsi produk dan jasa yangakan dijual.

3) Sosial media.

4) Jaringan sosial media dapat dimanfaatkan untuk tempat memasarkan produk. Contohnya seperti facebook, twitter, Whatsapp, Instagram dll.

5) Melalui marketplace.

6) Pemberitahuan informasi produk untuk menawarkan barang/jasa kepada konsumen dapat dilakukan secara massal melalui marketplace seperti Tokopedia, Bukalapak, Shopee, Lazada dan lain-lain.

7) Forum atau komunitas.

Setelah penyampaian materi berakhir, peserta diperlihatkan sosial media yang telah dibuat sebelumnya dalam memasarkan salah satu produk UMKM yang ada di Desa Cibodas dengan harapan seluruh peserta lebih memahami materi yang diberikan. Akun yang digunakan sebagai contoh adalah akun Instagram pesona.desa.cibodas yang bekerjasama dengan pihak Desa Cibodas.

\section{Pendampingan Peserta.}

Setelah sesi penyampaian materi selesai dilanjutkan dengan pendampingan peserta untuk mengenal lebih dekat aplikasi dan sosial media yang digunakan untuk memasarkan produk mereka dengan fasil setiap kelompok yang telah ditentukan sebelumnya agar penyampaian materi berjalan dengan baik yang diawali dengan mengunduh aplikasi, mendaftarkan akun, hingga produk yang mereka buat dapat dipasarkan pada aplikasi dan social media yang digunakan seperti pada tokopedia, shopee, facebook, instagram dan sebagainya. Selama proses workshop berlangsung peserta sangat antusias menerima materi yang diberikan dengan mengajukan pertanyaan - pertanyaan serta mendengarkan seluruh materi yang diberikan dengan diadakannya workshop 


\begin{tabular}{|c|c|c|c|c|}
\hline JURNAL & \multirow{2}{*}{ VOLUME 3} & \multirow{2}{*}{ NOMOR 1 } & \multirow{2}{*}{ HALAMAN 41-50 } & $\begin{array}{l}\text { ISSN 2655-8823 }(p) \\
\text { ISSN 2656-1786 }(e)\end{array}$ \\
\hline
\end{tabular}

tersebut pelaku UMKM di Desa Cibodas berharap dapat meningkatkan pereknomian mereka.

\section{Tahapan Monitoring dan Evaluasi.}

Pada tanggal 29 Januari 2020 kami mendatangi UMKM opak untuk melakukan monitoring dan evaluasi dari workshop sebelumnya didapatkan bahwa UMKM tersebut belum sepenuhnya paham akan memasarkan produk yang mereka pasarkan di aplikasi atau sosial media oleh karena itu kami mendampingi UMKM opak dalam memasarkan dan mengelola akun sosial media dan aplikasi yang mereka gunakan dalam memasarkan opak. Akun yang telah dibuat selanjutnya akan dilanjutkan oleh putri pemilik UMKM opak yaitu teh Pipit karena pengelihatan beliau kurang baik dalam menggunakan ponsel.

Indikator keberhasilan dari pengabdian ini adalah telah dilaksanakan kegiatan workshop dan dibuatnya laman UMKM yang ada di Desa Cibodas khusunya industri opak ketan cibodas pada media sosial dan berbagai macam aplikasi seperti facebook, instagram, dan tokopedia guna memaksimalkan penjualan mereka. Hasil dan dari kegiatan ini diharapkan bermanfaat bagi UMKM opak khususnya untuk meningkatkan penjualan sehingga dapat lebih banyak memberdayakan masyarakat sekitar serta evaluasi dari kegiatan ini dapat menjadi masukan bagi pengabdian di masa yang akan datang.

\section{KESIMPULAN DAN SARAN}

Aktivitas pengabdian yang menggunakan metode penelitian dan pengembangan (research and development) ini telah menghasilkan sejumlah luaran sebagai berikut:

1. Kondisi usaha dari usaha Opak yang dikembangkan oleh warga masyarakat dan pengusaha di lingkungan Desa Cibodas

2. Perumusan solusi berbasis analisa dan data dan informasi yang dikembangkan dari temuan nyata di lapangan. Hal yang dirumuskan dalam konteks ini adalah pentingnya membangun modul pemasaran digital untuk kepentingan lokakarya dan pelatihan, serta membangun ruang pemasaran digital di dunia maya

3. Edukasi Kewirausahaan dalam bentuk lokakarya dan pelatihan kepada pelakua usaha di Desa Cibodas

4. Terbangunnya kesadaran terkait urgensi pemasaran digital dan meningkatnya pemahaman tentang cara membangun ruang pemasaran di dunia maya.

Saran yang dapat diberikan adalah sebaiknya kedepannya dilakukan kembali monitoring untuk mengetahui apakah terdapat hambatan dalam melakukan pemasaran produk secara online. Setelah data mengenai hambatan yang banyak ditemui dikumpulkan, tim dapat meninjau apakah kegiatan lanjutan diperlukan untuk mengatasi hambatan tersebut.

\section{DAFTAR PUSTAKA}

Drath, R., \& Horch, A. (2014). Industrie 4.0: Hit or hype? [Industry Forum]. IEEE Industrial Electronics Magazine, 8(2), 56-58. https://doi.org/10.1109/MIE.2014.2312 079

Fawaid, A. (2017). Pengaruh Digital Marketing System, Terhadap Daya Saing Penjualan Susu Kambing Etawa. IQTISHADIA: Jurnal Ekonomi \& Perbankan Syariah, 4(1), 104-119. https://doi.org/10.19105/iqtishadia.v4i 1.1134

Karlina, N., Halim, H. A., Azizi, M. F., Athusholihah, A., \& Tarliyah, A. (2020). Pemberdayaan Jiwa Kewirausahaan Masyarakat Desa Cisempur dan Pendampingan Kewirausahaan Berbasis Ecommerce. Kumawula: Jurnal Pengabdian Kepada Masyarakat, 2(3), 262-269. https://doi.org/10.24198/kumawula.v2i 3.24592

Kotler, P., Kartajaya, H., \& Setiawan, I. (2017). Marketing 4.0: Moving from Traditional to Digital. New Jersey: 


\begin{tabular}{|c|c|c|c|c|}
\hline JURNAL & \multirow{2}{*}{ VOLUME 3} & \multirow{2}{*}{ NOMOR 1 } & HALAMAN 41-50 & $\begin{array}{l}\text { ISSN 2655-8823 }(p) \\
\text { ISSN 2656-1786 }(e)\end{array}$ \\
KOLABORASI RESOLUSI KONFLIK
\end{tabular}

John Wiley \& Sons, Inc.

Kristiyanti, M., \& Rahmasari, L. (2015).

Website sebagai Media Pemasaran

Produk-Produk Unggulan UMKM di

Kota Semarang. Jurnal Aplikasi Manajemen, 13(2), 186-196. Retrieved from

https://jurnaljam.ub.ac.id/index.php/ja $\mathrm{m} /$ article/view/760/719

Nassazi, A. (2013). Effects of training on Employee performance: Evidence from Uganda. Vaasa: VAASAN AMMATTIKORKEAKOULU UNIVERSITY OF APPLIED SCIENCES International Business.

Neugebauer, R., Hippmann, S., Leis, M., \& Landherr, M. (2016). Industrie 4.0 From the Perspective of Applied Research. Procedia CIRP, 57, 2-7. https://doi.org/10.1016/j.procir.2016.1 1.002

Prasetyo, H., \& Sutopo, W. (2018). INDUSTRI 4.0: TELAAH KLASIFIKASI ASPEK DAN ARAH PERKEMBANGAN RISET. J@ti Undip : Jurnal Teknik Industri, 13(1), 17.

https://doi.org/10.14710/jati.13.1.1726

Rachmawati, I. N. (2007). Pengumpulan
Data dalam Penelitian Kualitatif: Wawancara. Jurnal Keperawatan Indonesia, 11(1), 35-40. https://doi.org/10.7454/jki.v11i1.184

Rosaliza, M. (2015). Wawancara Sebuah Interaksi Komunikasi dalam Penelitian Kualitatif. Jurnal Ilmu Budaya, 11(2), 71-79.

https://doi.org/10.31849/jib.v11i2.1099

Sugiyono. (2019). Metode Penelitian Kuantitatif Kualitatif dan $R \& D$. Bandung: Alfabeta.

Sukoco, I., Fordian, D., \& Rusdin. (2019). Pelatihan Dasar dan Workshop Kewirausahaan di Desa Cintaratu Kabupaten Pangandaran. Kumawula: Jurnal Pengabdian Kepada Masyarakat, 2(3), 1-7. https://doi.org/10.24198/kumawula.v1i 3.24076

Sulisworo \& Fahmi, Irfan. (2019). Observasi Psikologi. Bandung: PT Rosdakarya.

Suprayekti, \& Anggraeni, D. S. (2017). Pelaksanaan Program Workshop "Belajar Efektif" Untuk Orang Tua. JIV-Jurnal Ilmiah Visi PGTK PAUD Dan DIKMAS, 12(2), 129-136. https://doi.org/10.21009/jiv.1202.5 